

\title{
Role And Importance Of Advocacy In Legal Support Of Business Entities
}

Copyright: Original content from this work may be used under the terms of the creative commons attributes 4.0 licence.

\section{Nurumov} Independent Researcher At Tashkent State University Of Law Senior Teacher Of Judicial, Law Enforcement Bodies And Advocacy Department Of TSUL, Uzbekistan

\section{ABSTRACT}

The article considers the role of attorneys in assisting business development and their importance in legal protection of entrepreneurs. The author emphasizes a set of features of advocacy and advantages of attorney over in-staff lawyer of an enterprise

\section{KEYWORDS}

Advocacy, business, attorney, legal protection of business

\section{INTRODUCTION}

Development of the Republic of Uzbekistan, just as any other country, largely depends on a highly developed and efficient private business. Thanks to successful implementation of reforms, this sector today plays a key role in modernization of the country's national economy. Special attention in our republic is paid to liberalization of economy, introduction of market principles and management 
mechanisms, development of private property and entrepreneurship.

Despite difficulties and obstacles being faced, private entrepreneurship is developing and rapidly growing, simultaneously solving economic, social, scientific and technical problems. The state guarantees freedom of business activity and entrepreneurship. In accordance with the Constitution of the Republic of Uzbekistan, private property, along with other forms of property, is inviolable and protected by the state. The owner owns, uses and disposes of the property belonging to him at his own discretion.

As a result of the measures taken, the share of small business and private entrepreneurship in the gross domestic product in our country increased from $31 \%$ in 2000 to $56 \%$ at present, and in industrial production - from $12.9 \%$ to $31.1 \%[1]$ appropriately. More than $77 \%$ of the employed population currently work in this area against $49.7 \%$ in 2000 . For example, over a million jobs in 2019 were created in the sphere of small business and private entrepreneurship. 25,7 thousand new small businesses were launched, showing an increase of $6 \%$ compared to 2018. These business entities were leased 20,8 thousand units of unused state property and a total amount of 1,6 trillion soums was given as bank and micro loans. Meanwhile, according to the Central Bank of the Republic of Uzbekistan, the volume of loans allocated in ten years (from 2000 to 2010) by commercial banks to small businesses and private entrepreneurship increased 26 times and reached 2,7 trillion soums, out of which 485.2 billion soums were given as microcredits showing a 39 times increase [2].
In addition, the number of state statistical, financial, tax and other types of reports by business entities was radically reduced in accordance with the requirements of a market economy and international norms and standards in order to improve the business environment, create favorable conditions for business entities by eliminating bureaucratic barriers, reducing and simplifying licensing procedures [3] As a result, submission of tax reports on all types of taxes and other mandatory payments on a monthly basis was cancelled, micro-firms are obliged to fill in statistical reports only on annual basis, with state statistical authorities' quarterly sample surveys in relevant areas of activity.

The foremost objective of the Government's activity in this direction is to further strengthen legal protection of private property, small business and private entrepreneurship, as well as to strengthen liability of law enforcement, regulatory and other government officials for obstruction and illegal interference in activities of business entities. Introduction of "single window" principle is becoming widespread when registering property, allocating land plots, obtaining licenses to engage in certain types of activities, issuing construction permits and connecting to power supply networks.

The World Bank's annual Doing Business Index compares 189 countries around the world on 10 indicators of doing business conditions. With 69.9 points, the country took 69th place in the overall ranking among 190 countries (back in 2014 we held149th place) [4] .

Since the compilation of the Rating in 2018, more than 40 legislative acts in the field of entrepreneurship have been supplemented and changed. When assessing the World Bank experts took into account not only the norms 
enshrined in legislation but also their practical implementation.

Nevertheless, we should not forget about the role of attorneys when talking about the development of entrepreneurship. Small business needs attorneys' legal assistance most, since subjects of medium and large business have a wide staff of lawyers of various specializations and usually do not need attorney services.

Subjects of small business are business entities (legal entities and individual entrepreneurs) classified in accordance with legislation to small enterprises, including micro enterprises. When doing business, small businesses may face various unfavorable legal cases (failure to fulfill obligations, claims of counterparties, penalties from government bodies, labor disputes, etc.) in addition to economic risk factors, which can lead to financial losses.

To avoid such situations or reduce financial losses from them to a minimum, many organizations and individual entrepreneurs may hire an in-staff lawyer who deals with all legal issues related to the activities of the employer - from the drafting and conclusion of contracts to litigation.

However, not every individual entrepreneur or organization has the opportunity to afford an in-staff lawyer on a permanent basis, or even feel the need for him.

Such notion is erroneous in any case and can lead to bad results. This is primarily due to the fact that most of individual entrepreneurs, founders of organizations or their CEOs don't have legal knowledge and practice of its application. This legal illiteracy can lead to mistakes when concluding or executing civil or labor contracts, low procedural activity in court proceedings and when enforcing court decisions, and, as a result, lack of efficiency in preserving and increasing capital. In addition, certain difficulties in dealing with such public authorities as tax bodies, labor inspectorates, prosecutors and local authorities are also worth mentioning.

A certain reasonable way out of this situation is the "episodic" involvement of an attorney for legal assistance. This point of view can be substantiated with the following arguments.

Firstly, according to Article 5 of the Law of the Republic of Uzbekistan "On Advocacy", an attorney provides advice and information on legal issues, draws up statements, complaints, petitions, etc., participates as a representative in administrative, civil, criminal, economic courts, represents the interests of the client in state bodies.

At the same time, the law does not restrict the right of individual entrepreneurs and commercial organizations to receive legal assistance from an attorney. In fact, it provides a wide range of legal assistance forms that small businesses can use when contacting an attorney. Usually, most basic ones are execution of paperwork (drafting contracts, complaints, statements of claim), participation in court proceedings as a representative. Representation of client's interests in state and local authorities is a specific type of legal assistance and usually factual participation of an attorney is not often required.

Consulting client before he goes to state body may be just enough in view of the fact that state or local government bodies usually either adopt an act entailing punishment of the entrepreneur (organization), or a certain issue 
is agreed upon. In relation to these frequently made decisions, it is possible to:

- Appeal to the court (for example, an act of a state body on imposing an administrative penalty);

- Filing a claim with the court (with a requirement to compel the conclusion of a contract).

Speaking about an essential role of an attorney in legal assistance to small businesses, it is necessary to highlight a number of advantages of this assistance over the work of a full-time lawyer.

Firstly, the Law of the Republic of Uzbekistan "On Advocacy" provides for a number of duties that an attorney must fulfill. In particular:

- Honestly, reasonably and conscientiously protect the rights and legitimate interests of the principal;

- Constantly improve his knowledge and improve qualifications;

- Comply with the Attorney's code of professional ethics.

In addition to this, the aforementioned law contains a number of restrictions for an attorney. He is not entitled to:

- Disclose the information provided to him by the principal in connection with provision of legal assistance to the latter, without the consent of the principal;

- Accept an order from a person who applied to him for legal assistance, if attorney himself has an independent interest in the subject of the agreement with the principal, which is different from the interest of this person;
- Take position on the case against the will of the principal.

These provisions can guarantee an individual entrepreneur (commercial organization) proper, high-quality and conscientious provision of legal assistance by an attorney since he can be held liable for non-compliance.

Secondly, this law contains a provision concerning attorney-client privilege, that is, confidentiality of information related to provision of legal assistance by an attorney to his client.[5] . Unlike an ordinary lawyer of any company, an attorney cannot be summoned and interrogated as a witness about the circumstances that became known to him in connection with legal assistance or in connection with its provision. It is an undoubted advantage, because every individual entrepreneur or every commercial organization, first of all, is interested in preserving any confidential information about their activities.

Thirdly, according to the requirements of the Code of Civil Procedure, the party in favor of which judicial decision was made can also compensate costs of paying for the services of a representative[6]. Each time an attorney enters into an agreement with a client, payment for his assistance is made through the cash desk of appropriate law firm and this which allows to officially confirm corresponding expenses with cash receipt order etc. In addition, you can also apply to the court with for partial recovery of attorney expenses from the plaintiff if the claim is partially satisfied. These statutes provide some discipline for individuals who often file claims on dubious legal grounds. 
Meanwhile, it can be often heard that attorneys ask for excessive amounts of money for their assistance. In this case, it should be noted that an agreement concluded between an attorney and an entrepreneur or a commercial organization, by its legal nature, gives its parties the right to independently determine attorney fee. With a reasonable approach to this issue by both parties, the cost of legal assistance of an attorney can be quite feasible for an applicant.[7] .

And finally, it is worth paying attention to the following competence of an attorney that undoubtedly puts him one step above a fulltime lawyer in protecting the rights of entrepreneurs in court. According to Article 6 of the Law of the Republic of Uzbekistan "On Advocacy", an attorney has the right to collect information necessary for provision of legal assistance, including requesting certificates, characteristics and other documents from public authorities, local authorities, as well as public associations and other organizations. These agencies and organizations are obliged to give the requested documents or certified copies thereof not later than 15-day period from the date of receipt of an attorney's request[8]. This provision gives a certain advantage in rapid obtaining necessary information without making corresponding requests to the judge, either during consideration of the case or before filing a claim with the court.

Summing up, it seems necessary to note that overcoming certain stereotypes of using services of attorneys in business society, associated with distrust, fear of large expenses, will undoubtedly have a beneficial effect on bringing closer small businesses and attorney. At the same time, an attorney must also take into account interests of small businesses, "be vigilant and always ready to rush into battle for his client".[9]

As a result of this interest consolidation, freedom of economic activity and protection of all forms of ownership can be ensured, ultimately contributing significantly to the formation of rule of law and civil society.

\section{REFERENCES}

1. Zhabbarov M. E. Main directions of development of the regulatory framework in the field of small business and private entrepreneurship in the Republic of Uzbekistan // Young scientist. 2016. - No. 11 (115). - p. 736-739. - URL: https://moluch.ru/archive/115/31006/

2. https://uzreport.news/finance/vuzbekistane-za-10-let-obemyikreditovaniya-mbchp-vyirosli-v-26-raz

3. Decree of the President of the Republic of Uzbekistan No. UP-4453 "On measures to radically reduce statistical, tax, financial reporting, licensed activities and licensing procedures" dated 16.07.2012

4. https://www.norma.uz/nashi_obzori/uzbe kistan_podnyalsya_na_7_strochek_v_doi ng_business

5. Article 9 of the Law of the Republic of Uzbekistan "On Advocacy"// Bulletin of the Oliy Majlis of the Republic of Uzbekistan, 1997, No. 2, art. 48; 2001, No. 1-2, Art. 23.

6. Article 136 of the Civil Procedure Code of the Republic of Uzbekistan // National Database of Legislation, 23.01.2018, No. 02/18 / GPK / 0612 
7. Advocacy in Russia: textbook. In 2 parts.

Part 2 / Ed. I. L. Trunova. - M .: Eksmo. 2007 .- p. 741.

8. Article 7 of the Law of the Republic of Uzbekistan "On Advocacy"// Bulletin of the Oliy Majlis of the Republic of Uzbekistan, 1997, No. 2, art. 48; 2001, No. 1-2, Art. 23.

9. Sergeev V.I. Business attorneys, do not lose your vigilance // Bar Chamber. - 2009. - No. 6. - P. 18 